February 1942

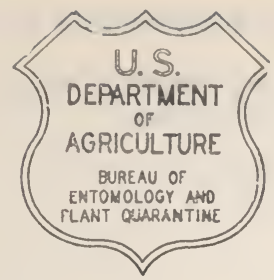

E-559

MAY BEETLES, OR JUNE BUGS, ON PECAN IN LOUISIANA

By W. C. Pierce, Division of Fruit Insect Investigations 1/

Introduction

Fifteen species of May beetles, or "June bugs" (Phyllophaga spp.), have been observed attacking the foliage of pecan trees in Louisiana. These beetles have been sufficiently abundant at periodic intervals completely to cefoliate large numbers of pecan trees in the northern and western portions of the State. The damage has been more extensive on pecans growing in upland soils. but young pecan trees growing in river bottoms have also suffered severe injury.

Observations of injury on pecan in Louisiana by Howard Baker and the writer from 1929 through 1937 have indicated that May beetles are aburdant at 2-year intervals. During this period the beetles were most abundant in 1929, 1931, 1933, 1935, and 1937.

\title{
Nature of Injury
}

May beetles feed on and cut off opening buds, shoots, leaves, and flowers of pecan trees during the early part of the growing season, before the young nuts have formed. Trees completely defoliated by beetle feeding make very little growth during the first 2 months of the growing season, make poor or ragged growth thereafter, and produce no nuts.

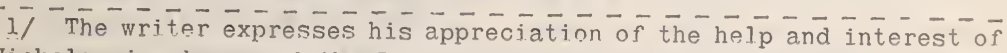
C. B. Nickels. in charge of the Brownwood, Tex., laboratory of the Bureau, under whose general direction this work was performed. Grateful acknowledgment is also made to E. A. Chapin. Curator of Insects of the U. S. National Museum, for identifications of the adult beetles, to A. G. Böving, of the Bureau of Entomology and Plant Quarantine, for identifications of the immature forms of Phyl lophaga, and to B. G. Sitton, of the Bureau of Plant Industry, at Shreveport, La., who aided in securing photographs of May beetle injury to pecan trees. 
Fifteen species of May beetles taken while feeding on pecan in Louisiana, 1934-1937, were as follows:

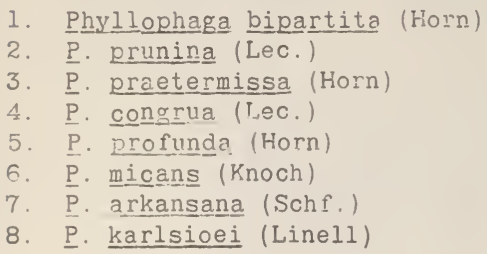

9. $\quad$ P. tristis (F.)
10.
11.
calceata (Lec.)
12.
13.
vehemens (Horn)
14.
gracilis (Burm)
15.
fervida (F.)
futilis (Lec.)

Observations of feeding and records on the number of specimens taken have indicated that the first seven species listed were responsible for most of the injury to pecan in Louisiana. Phyllophaga bipartita (Horn) was more abundant on pecan than all the other species combined.

Apparently, the species responsible for the most damage may vary in different localities of the pecan belt. Langston $2 /$ listed the pecan as a food plant of 33 species of May beetles in Mississippi.

\section{Other Trees Fed upon in Louisiana}

In addition to the pecan, May beetles were observed to cause partial or complete defcliation of hickory, post oak, red oak, persimmon, sweet gum, black gum, elm, and willow. Some damage is caused by the beetles in feeding on buds of roses before the flowers open.

\section{Feeding Period}

In Louisiana, May beetles usually begin feeding on pecan during the latter part of March, shortly after the buds begin to open. The dates on which llay beetles first appeared at Shreveport. La.. over a period of 3 years were: 1935, March 19; 1936, March 24; and 1937, March 22.

Late in March and early in April the extent of beetle feeding on pecan is influenced by the tempsratures prevailing at night. The beetles feed only on warm nights, and very few emerge from the soil when the temperature falls below $70^{\circ} \mathrm{F}$. at dusk. In 1935 the May beetle damage to pecans began on March 26, but practically no feeding occurred during the period April 6-14, with prevailing temperatures ranging from $44^{\circ}$ to $65^{\circ} \mathrm{F}$. In 1937 the first flight of heetles was observed on March 22, but low temperatures prevented damage to pecans from that date until April 10. The most extensive feeding on pecan occurs from April 15 to May 15 and is practically over by June 1 in northern Louisiana. Pecan trees defoliated by the beetles begin to recover during the latter part of May.

2/ Langston. J. M. 1927. Phyllophaga of Mississippi. Mississippi Agricultural Experiment Station Technical Bulletin No. 15. 
The lar.e. (white gruks) of May beetles feed on the roots of grasses and ber jiants. Ih $\mathrm{j}$ arc lisually more abuncant in uncultivated soils devoted to the ploduction of grasses than in cultirated soils. Conditions under which pecan trees were severely injured or completely defoliated by May tectles in Lorisia a were as follows: (1) Young pecan trees in both cultivated and unculti ated orchards, 10 to 40 acres in area, located near sod land; 2) old pscan tf cs growing in the outer rows of well-cultivated

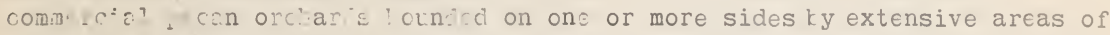
sod land; 3 pecen tre.s groving in Iards near homes; and (4) old pecan trees in u.bultivat.d. lcwtings, varsing from a few trees to large orchard tracis yelicilli su. roundzc bs sod land (fig. J.). Practically no damage isalsed j ite _....... un cen tr..s in well-cultivated commercial orchards surrouncic $! y$ large truc:. o. cultivated farm lanc's.

Some outsici scuces of infestations in cultivated pecan orchards nero meacuns, rasturos, cut-o:er ;oocilands, levees, road sides, and fence

\section{Control 3/}

Thor jugl. cu.ti.ation renever possible of all areas in or near pecan orohards, in which ite white griks, or beetle lariae, may develop is of grce. alue in osntiol. Since this is not always feasible, other control - a.c n...... $0_{1}$ th int injury to pecan trees by the beetles.

Experiments were conciucted near Shreveport, La,, in 1935 and 1937 , to study the effect of arsenical sprays in preventing damage by May beetles on joung pecan trecs. One application of lead arsenate failed to produce conclusire results in 1935 on a light infestation of the beetles. A single application of lead arsenate, 3 to 4 pounds in 100 gallons of water, caused no injury to pecan foliage that year.

In 1937 lead arsenate was used at the rate of 3 pounds to 100 gallons of water in combination with 3 pounds of hydrated lime. Twenty-nine pecan trees in an orchard containing 114 trees were sprayed with this material at weekly intervals for 5 weeks. The first spray application was made on April 20, and the last on Nay 19, 1937. Differences in the extent of beetle injury on sprayed and unsprajec tress first became apparent 4 to 6 days after the date of the first spray application.

Srrajed trees retains their foliage and continued growth, while the amount of foliage on unsraysd trees decreased with each night of beetle feoding until all unsprayed trees were completely defoliated. Photographs of sprayed and unsprayzd trues (figs. 2 and 3) were taken on May 14 and

3/ For more detailad infornation on May beetle control, particularly with reference to the gruk stage, see Farmers' Bulletin No. 1798, U. S. Department of Agriculture, Control of Comon White Grubs in Cereal and Forage Crops. 
May 27, 1937. to show the results secured by spraying with lead arsenate to prevent May beetles from defoliating pecan trees.

Five applications of the lead arsenate spray caused burning of the foliage on sprayed trees from 2 to 6 weeks after the last spray was applied. Foliage injury was severe on 6 trees and was of no practical importance on the remainder of the sprayed trees.

The discontinuance of the work in northern Louisiana prevented further experiments with spraying for beetle control. It is believed, however, that three properly timed spray applications, starting when the beetles first appear, should give reasonable protection. This should be used only in areas in which experience has indicated that lead arsenate can be applied without serious burning of the foliage. The danger of foliage injury should of course be less with three applications than with five, as used in the experiments.

The average quantity of spray liquid required in the experiments of 1937. for the trees which varied from 8 to 20 feet in height, was approximately 4 gallons. With lead arsenate at 12 cents per pound. and hydrated lime at $2 / 3$ cent per pound, the cost for spray materials per application would average about $1 \frac{1}{2}$ cents for trees of the sizes shown in figures 2 and 3 . The spraying of larger, older trees would of course cost more, but trees of this type are less likely to need protection. 


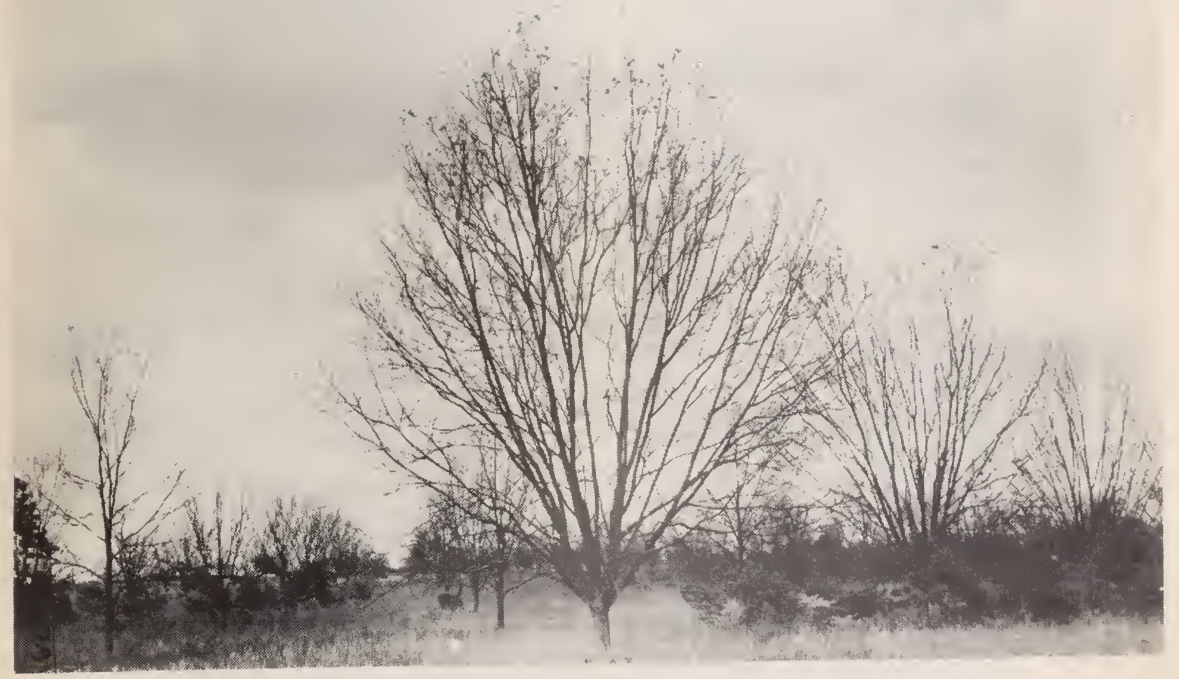

Figure 1.-View of an uncultivated pecen orchard May 13, 1937, shoving a large tract of old pecan trees completely defoliated by May beetles.

\section{LIBRARY STATE PLANT BOARD}




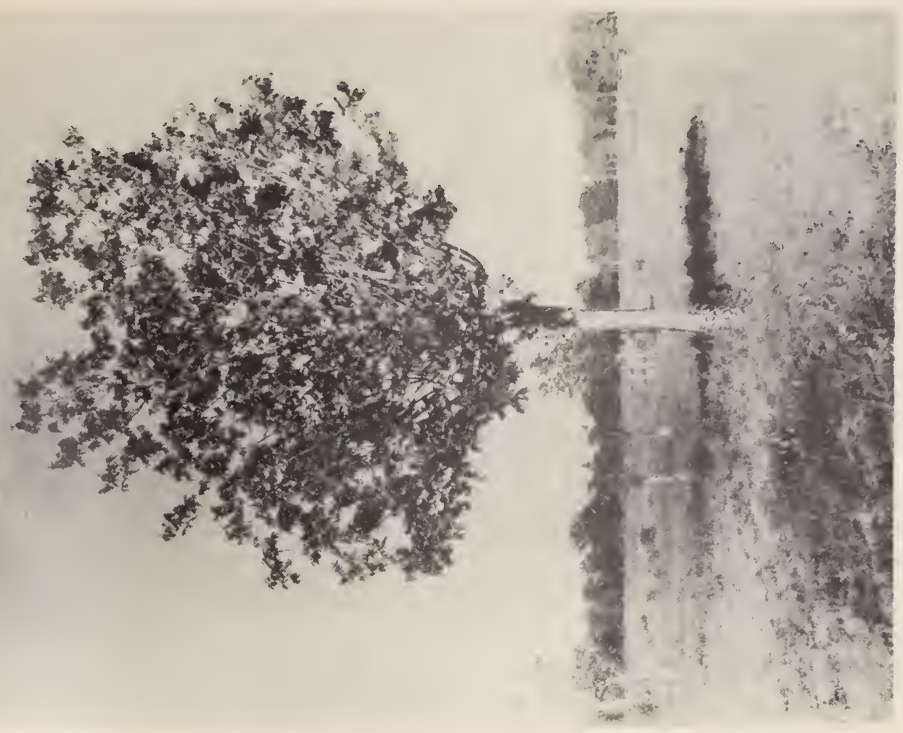

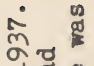

न्म बू कू

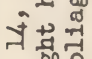

मे क्त

$\geq$

동혀

뎡 0

के कै कै

$4+3$

+ ㅎํ

워 के 능

क. है थ

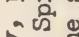

के

() $् न$

क्ष 10

5 겅

1) क

+ 8 \&

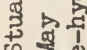

म

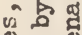

(1)

मे क्ष 4

क ल

मै

๑ स्ष $न 1$

व 0

잉

के क्ष क्षै

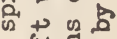

- 1 है

मี न-1 क्ष

ช

\& थ न

के $\$$ م

के कै के क्ष

व +

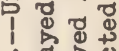

i के 5

क्षे

\& ट्वे \&

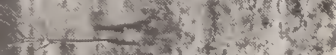

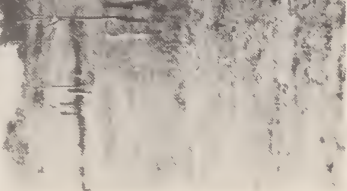

3 क म है हैy 


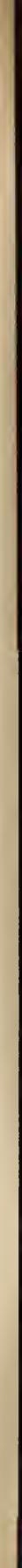




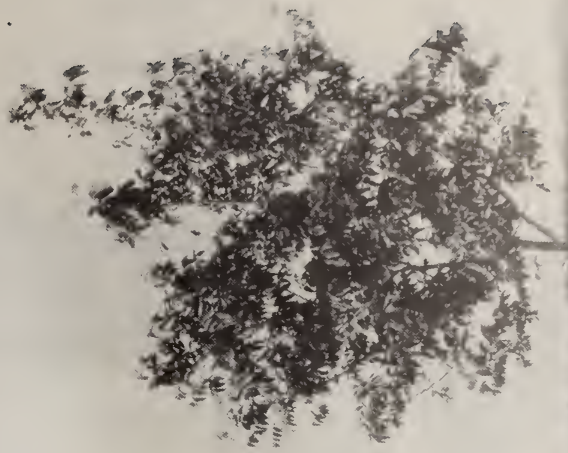

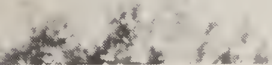
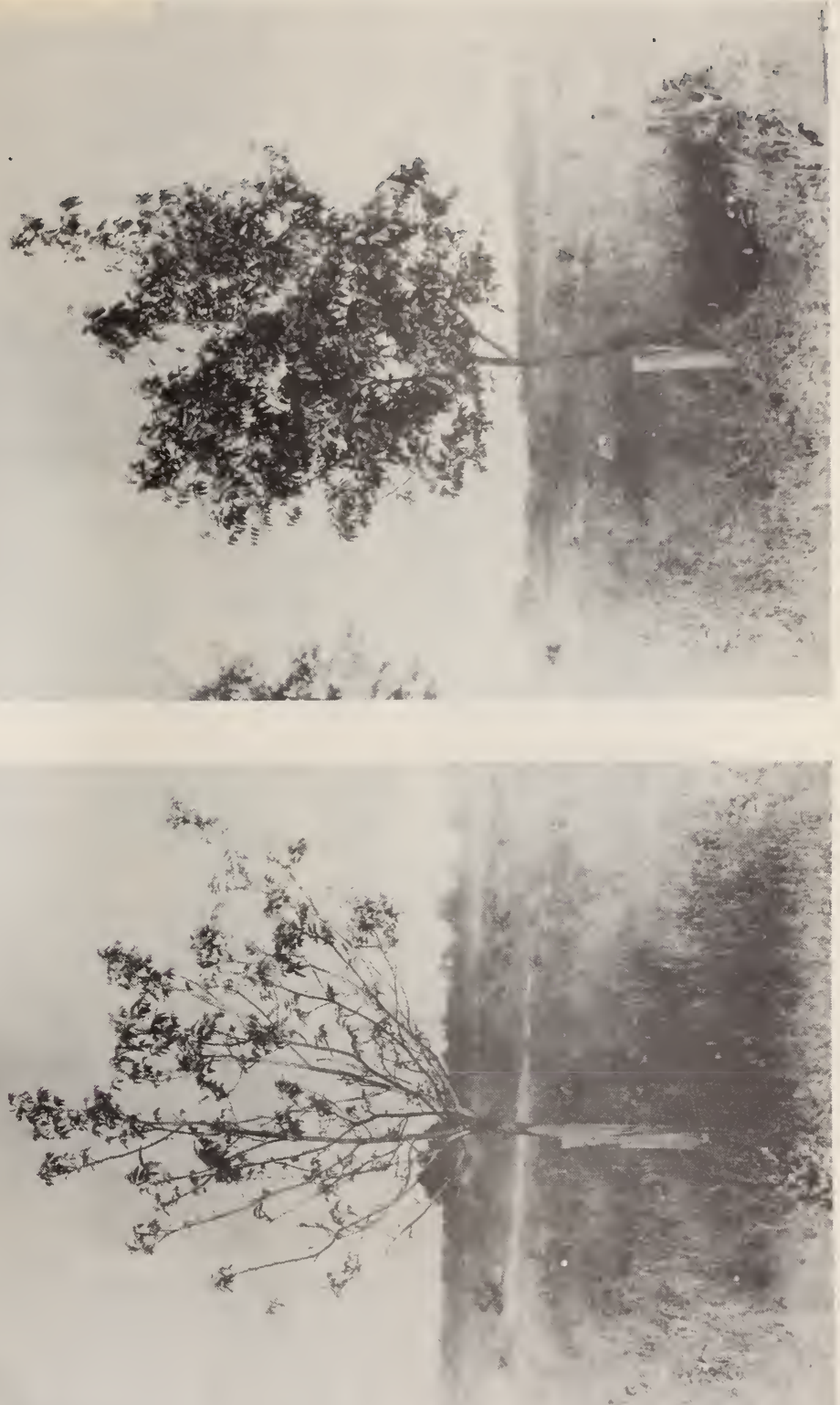

"ृ.

뭉ํำ

的

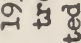

a d

స

$\rightarrow$ a

용

'

c.

क्ष

50

요

궁

표

में

당

ฐँ 궐

$+7$

दो 단

范嵒

ज4

के क्ष

on

ţ

क्ष

o

8 \& 8

눈

ํㅣㅇ 幽 \%

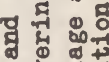

$\rightarrow-1$

ช 겅

क

औ 7 क

产 ड्न न्न ! 믕 대웡 m 芹 दै⿴囗十丁 id 
